\title{
A Study on Students' Learning Strategies and Self-efficacy in Speaking I Class in ELESP of Sanata Dharma University
}

\author{
Yohana Vita Lelita \\ Sanata Dharma University
}

\begin{abstract}
Speaking skill is a skill that is judged first than other skills by someone in many languages. This perspective is the underlying reason why ELESP students are demanded to have good speaking ability. Having a good speaking ability will also give them many other benefits. Based on the researcher's personal experiences as the first semester student and experiences of doing micro teaching in Speaking I class, it was found that some ELESP students' speaking ability was not good enough. This study aims to find out the language learning strategies ELESP students applied to improve their speaking ability and the use of those strategies in relation to the students' self-efficacy by distributing questionnaire and conducting interview.
\end{abstract}

Keywords: language learning strategies, self-efficacy, speaking ability

\section{Introduction}

Speaking skill is a skill that is judged first than other skills by someone in many languages (McDonough \& Shaw, 2003). It means that people assess someone's language capability from his/her speaking skill first rather than listening skill, reading skill and writing skill. Therefore, ELESP students should have good or even high speaking ability. Having good speaking ability also gives them other benefits such as making them good teachers. If they have good speaking ability, there will be no misunderstanding between them and their students when communicating and explaining the learning material.
Another benefit is making them able to communicate with many people from many other countries and in many situations or occasions (Harmer, 1991). Based on the researcher's personal experiences as the first semester student and experiences of doing micro teaching in Speaking I class, it was found that some ELESP students' speaking ability was not good enough. Their speaking ability still required substantial improvement.

Oxford (1990) states that strategies are important for language learners because they are tools to develop their communicative ability. Doing appropriate language learning strategies will improve students' 
ability. Therefore, ELESP students need to apply appropriate language learning strategies in order to improve their speaking ability. From the analysis of language learning strategies, the researcher will understand the use of those strategies and the relation between it and the students' self-efficacy. For this reason, this study would like to address two questions. First, what language learning strategies were applied by the students to improve their speaking ability in Speaking I class? Second, what is the use of those strategies in relation to the students' self-efficacy?

To answer both research questions, the researcher distributed questionnaire and conducted an interview. The questionnaire was given to twenty two students of ELESP in Speaking I class B of Sanata Dharma University in academic year 2015/2016. The questionnaire was distributed to analyze the language learning strategies they applied, the effort they put when encountering obstacles, the beliefs in their ability to achieve goals, and the use of language learning strategies as reflected in their speaking performance. The analyses of those things were used to get better understanding of their self-efficacy. Furthermore, to analyze the relation between the use of those strategies and the students' self-efficacy, the researcher conducted an interview with three students of Speaking I class B.

\section{Theoretical Ground}

\section{Language Learning Strategies} Used to Improve Speaking Ability According to Oxford (1990), there are six types of language learning strategies. Each of the strategies is explained in the following table.

\section{Table 1 Language Leaning Strategies}

\begin{tabular}{|c|l|l|}
\hline LLS & \multicolumn{1}{|c|}{ Explanation } & \multicolumn{1}{c|}{ Examples } \\
\hline \multirow{3}{*}{$\begin{array}{c}\text { Memory } \\
\text { Strategies }\end{array}$} & $\begin{array}{l}\text { These are strategies that help } \\
\text { learners keep and retrieve } \\
\text { new information. }\end{array}$ & $\begin{array}{l}\text { Using phonetic spelling and/or } \\
\text { accent marks to memorize new } \\
\text { words. }\end{array}$ \\
\cline { 3 - 3 } & $\begin{array}{l}\text { Remembering difficult English } \\
\text { grammar by reviewing it many } \\
\text { times. }\end{array}$ \\
\hline \multirow{2}{*}{$\begin{array}{c}\text { Cognitive } \\
\text { Strategies }\end{array}$} & $\begin{array}{l}\text { Cognitive strategies enable } \\
\text { learners to understand and } \\
\text { produce new language in } \\
\text { many different meanings. }\end{array}$ & $\begin{array}{l}\text { Practicing pronunciation by doing } \\
\text { repetition }\end{array}$ \\
\cline { 3 - 3 } & $\begin{array}{l}\text { Joining a foreign language club and } \\
\text { making friends with native } \\
\text { speakers. }\end{array}$ \\
\hline \multirow{2}{*}{ Compensatio } & $\begin{array}{l}\text { These strategies help } \\
\text { learners overcome gaps in } \\
\text { knowledge so learners can }\end{array}$ & $\begin{array}{l}\text { Using mother tongue without } \\
\text { translating it if learners do not } \\
\text { know how to say it in target }\end{array}$ \\
\hline
\end{tabular}




\begin{tabular}{|c|c|c|}
\hline \multirow[t]{3}{*}{ n Strategies } & \multirow[t]{3}{*}{ communicate authentically. } & language. \\
\hline & & $\begin{array}{l}\text { Using mime, gesture or physical } \\
\text { movements as the expression to } \\
\text { show the meaning of certain words }\end{array}$ \\
\hline & & $\begin{array}{l}\text { Using synonym to show what the } \\
\text { learners want to say. }\end{array}$ \\
\hline \multirow{3}{*}{$\begin{array}{c}\text { Metacognitiv } \\
\text { e Strategies }\end{array}$} & \multirow{3}{*}{$\begin{array}{l}\text { These strategies give } \\
\text { learners a way to manage } \\
\text { and organize their learning } \\
\text { process. }\end{array}$} & $\begin{array}{l}\text { Making time schedule to practice } \\
\text { speaking. }\end{array}$ \\
\hline & & $\begin{array}{l}\text { Setting goals or making long-term } \\
\text { aim which refers to the result that } \\
\text { will be accomplished in many } \\
\text { months or years later. }\end{array}$ \\
\hline & & $\begin{array}{l}\text { Evaluating learners' progress in } \\
\text { speaking a new language. }\end{array}$ \\
\hline \multirow{2}{*}{$\begin{array}{l}\text { Affective } \\
\text { Strategies }\end{array}$} & \multirow{2}{*}{$\begin{array}{l}\text { Affective strategies enable } \\
\text { learners to control their } \\
\text { emotions and attitudes } \\
\text { towards learning. }\end{array}$} & $\begin{array}{l}\text { Taking deep breath before starting } \\
\text { speaking to reduce anxiety. }\end{array}$ \\
\hline & & $\begin{array}{l}\text { Saying positive statement to } \\
\text { encourage learners to speak } \\
\text { English. }\end{array}$ \\
\hline \multirow[t]{2}{*}{$\begin{array}{l}\text { Social } \\
\text { Strategies }\end{array}$} & \multirow{2}{*}{$\begin{array}{l}\text { These are strategies that help } \\
\text { learners to be able to } \\
\text { communicate with many } \\
\text { people by giving them } \\
\text { opportunities to practice } \\
\text { their speech production }\end{array}$} & $\begin{array}{l}\text { Having temporary pair or small } \\
\text { group to practice speaking with } \\
\text { others. }\end{array}$ \\
\hline & & $\begin{array}{l}\text { Having conversation with native } \\
\text { speakers that they meet outside the } \\
\text { classroom. }\end{array}$ \\
\hline
\end{tabular}

\section{Factors Influencing the Use of Language Learning Strategies}

According to Oxford (1990), there are some factors that influence the use of language learning strategies and determine their speaking performance, namely motivation and anxiety. Motivation is the primary source which contributes to individual language learning. Learners who have high motivation seem to use greater range of appropriate strategies. Motivation determines the amount of some components, namely goal, want, effort and attitudes toward the learning activity (Gardner, 1985).
Highly motivated individuals are more active in language classes, more successful in learning foreign language, and more excited to participate in foreign community and interact with members of that community.

Anxiety can affect learners' productive skill such as speaking skill, including the language learning strategies (Horwitz, 2001). Learners with low anxiety will succeed in their language learning because they tend to use various language learning strategies (Oxford, 1990). Anxiety is not only feeling anxious, but it also includes the feeling of doubtful, 
fearful, and even stressed. That will influence learners' belief on their capability in speaking English. Those feelings appear when individuals have beliefs in being not confident in their ability, being embarrassed and confused that they will make a mistake when performing challenging task.

\section{Self-efficacy}

Self-efficacy refers to individuals' beliefs in their capabilities to manage something and do some actions in order to achieve certain accomplishment (Bandura, 1997). Self-efficacy is not a measure of the skills one has but it is a belief in what one can do under certain conditions with whatever skills one possesses. Those beliefs give influence on some aspects, namely individuals' task orientation, effort and persistence, strategy use, beliefs, and performance. The table below summarizes how self-efficacy influences those aspects.

Table 2 The Influence of Self-efficacy

\begin{tabular}{|c|c|c|}
\hline & $\begin{array}{l}\text { High Self-efficacy } \\
\text { Individuals }\end{array}$ & $\begin{array}{l}\text { Low Self-efficacy } \\
\text { Individuals }\end{array}$ \\
\hline $\begin{array}{c}\text { Task } \\
\text { orientation }\end{array}$ & $\begin{array}{l}\text { High self-efficacy } \\
\text { individuals have high targets } \\
\text { and goals. Not only having } \\
\text { them, they do some things to } \\
\text { achieve their targets and } \\
\text { goals. They consider those } \\
\text { targets and goals as } \\
\text { challenges not as burdens. }\end{array}$ & $\begin{array}{l}\text { Low self-efficacy } \\
\text { individuals have low targets } \\
\text { and goals. Some of them } \\
\text { may have high targets and } \\
\text { goals, but they will do } \\
\text { fewer things or even } \\
\text { nothing to achieve them } \\
\text { because they have low } \\
\text { estimations of their } \\
\text { capabilities to perform } \\
\text { something. }\end{array}$ \\
\hline $\begin{array}{l}\text { Effort and } \\
\text { persistence }\end{array}$ & $\begin{array}{l}\text { High self-efficacy } \\
\text { individuals put more effort } \\
\text { and not easily give up when } \\
\text { facing obstacles. }\end{array}$ & $\begin{array}{l}\text { Low self-efficacy } \\
\text { individuals easily give up } \\
\text { and lose their spirit to keep } \\
\text { trying when facing } \\
\text { obstacles because they have } \\
\text { doubt about their } \\
\text { capabilities to perform } \\
\text { something. }\end{array}$ \\
\hline Strategy use & $\begin{array}{l}\text { High self-efficacy } \\
\text { individuals are likely to do } \\
\text { some actions or useful } \\
\text { strategies and have high } \\
\text { commitment to achieve their }\end{array}$ & $\begin{array}{l}\text { Low self-efficacy } \\
\text { individuals are not likely to } \\
\text { do some actions or useful } \\
\text { strategies and have weak } \\
\text { commitment to achieve }\end{array}$ \\
\hline
\end{tabular}




\begin{tabular}{|c|c|c|}
\hline & targets and goals. & their targets and goals. \\
\hline Beliefs & $\begin{array}{l}\text { High self-efficacy } \\
\text { individuals have high self- } \\
\text { confidence that they will be } \\
\text { able to achieve their targets } \\
\text { or goals. Besides, they can } \\
\text { control their stress and } \\
\text { anxiety when they cannot } \\
\text { achieve their targets and } \\
\text { goals yet. }\end{array}$ & $\begin{array}{l}\text { Low self-efficacy } \\
\text { individuals have low self- } \\
\text { confidence that they will be } \\
\text { able to achieve their targets } \\
\text { or goals. Besides, they } \\
\text { cannot control their feeling, } \\
\text { so they will feel anxious } \\
\text { and depressed when they } \\
\text { cannot achieve their targets } \\
\text { and goals yet. }\end{array}$ \\
\hline Performance & $\begin{array}{l}\text { High self-efficacy } \\
\text { individuals have higher } \\
\text { performance than low self- } \\
\text { efficacy individuals. }\end{array}$ & $\begin{array}{l}\text { Low self-efficacy } \\
\text { individuals have lower } \\
\text { performance than high self- } \\
\text { efficacy individuals. }\end{array}$ \\
\hline
\end{tabular}

Individuals' self-efficacy can be determined by understanding those five aspects (Bandura, 1986). Information in table 2 shows that individuals who use strategies more efficiently, do activities to achieve targets and goals willingly, expend greater effort, persist longer even if difficulties appear, believe that they can succeed and perform better than other people are individuals with high self-efficacy.

\section{Discussion}

1. Students' Choices of Language Learning Strategies

In order to answer the research question number one, the researcher distributed questionnaire sheets consisted of close-ended questions to 22 students in Speaking I class B and conducted an interview to three students. The research findings indicated that all students applied various language learning strategies to improve their speaking ability.

Table 3 Students' Choices of Language Learning Strategies

\begin{tabular}{|c|c|c|c|c|c|c|}
\hline $\begin{array}{l}\mathbf{N} \\
\text { o. }\end{array}$ & LLS & Statement & SD & D & A & SA \\
\hline 1. & \multirow{2}{*}{$\begin{array}{l}\text { Memor } \\
\text { y } \\
\text { Strategi } \\
\text { es }\end{array}$} & $\begin{array}{l}\text { I use phonetic spelling and/or } \\
\text { accent marks written in the } \\
\text { dictionary to memorize new } \\
\text { words. }\end{array}$ & $\begin{array}{c}0 \\
(0 \\
\%)\end{array}$ & $\begin{array}{c}2 \\
(9 \%)\end{array}$ & $\begin{array}{c}17 \\
(77 \% \\
)\end{array}$ & $\begin{array}{c}3 \\
(14 \% \\
)\end{array}$ \\
\hline \multirow[t]{2}{*}{2.} & & $\begin{array}{l}\text { I remember difficult English } \\
\text { grammar by reviewing it many } \\
\text { times. }\end{array}$ & $\begin{array}{c}0 \\
(0 \\
\%)\end{array}$ & $\begin{array}{c}6 \\
(27 \% \\
) \\
\end{array}$ & $\begin{array}{c}16 \\
(73 \% \\
)\end{array}$ & $\begin{array}{c}0 \\
(0 \%)\end{array}$ \\
\hline & & I practice my pronunciation by & 1 & 14 & 6 & 1 \\
\hline
\end{tabular}




\begin{tabular}{|c|c|c|c|c|c|c|}
\hline 3. & \multirow{2}{*}{$\begin{array}{l}\text { Cogniti } \\
\text { veStrat } \\
\text { egies }\end{array}$} & $\begin{array}{l}\text { saying English words over and } \\
\text { over. }\end{array}$ & $\begin{array}{l}(5 \\
\%)\end{array}$ & $\begin{array}{c}(63 \% \\
)\end{array}$ & $\begin{array}{c}(27 \% \\
)\end{array}$ & $(5 \%)$ \\
\hline 4. & & $\begin{array}{l}\text { I join a foreign language club } \\
\text { and make friends with native } \\
\text { speakers. }\end{array}$ & $\begin{array}{l}2 \\
(9 \\
\%)\end{array}$ & $\begin{array}{c}15 \\
(68 \% \\
)\end{array}$ & $\begin{array}{c}5 \\
(23 \% \\
)\end{array}$ & $\begin{array}{c}0 \\
(0 \%)\end{array}$ \\
\hline 5. & \multirow{3}{*}{$\begin{array}{l}\text { Compe } \\
\text { n- } \\
\text { sation } \\
\text { Strategi } \\
\quad \text { es }\end{array}$} & $\begin{array}{l}\text { When I do not know how to say } \\
\text { a word in English, I say it in } \\
\text { Bahasa Indonesia or Javanese as } \\
\text { my mother tongue. }\end{array}$ & $\begin{array}{l}0 \\
(0 \\
\%)\end{array}$ & $\begin{array}{c}2 \\
(9 \%)\end{array}$ & $\begin{array}{c}12 \\
(54 \% \\
)\end{array}$ & $\begin{array}{c}8 \\
(36 \% \\
)\end{array}$ \\
\hline 6. & & $\begin{array}{l}\text { When I forget the meaning of } \\
\text { certain English words, I use } \\
\text { mime, gesture or physical } \\
\text { movements to show it. }\end{array}$ & $\begin{array}{l}0 \\
(0 \\
\%)\end{array}$ & $\begin{array}{c}4 \\
(18 \% \\
)\end{array}$ & $\begin{array}{c}7 \\
(32 \% \\
)\end{array}$ & $\begin{array}{c}11 \\
(50 \% \\
)\end{array}$ \\
\hline 7. & & $\begin{array}{l}\text { When I forget the meaning of } \\
\text { certain English words, I use the } \\
\text { synonym of those words. }\end{array}$ & $\begin{array}{l}1 \\
(5 \\
\%) \\
\end{array}$ & $\begin{array}{c}5 \\
(23 \% \\
\quad) \\
\end{array}$ & $\begin{array}{c}14 \\
(63 \% \\
) \\
\end{array}$ & $\begin{array}{c}2 \\
(9 \%)\end{array}$ \\
\hline 8. & \multirow{3}{*}{$\begin{array}{l}\text { Metaco } \\
\text { g-nitive } \\
\text { Strategi } \\
\quad \text { es }\end{array}$} & $\begin{array}{l}\text { I make time schedule to practice } \\
\text { my speaking. }\end{array}$ & $\begin{array}{l}1 \\
(5 \\
\%)\end{array}$ & $\begin{array}{c}18 \\
(81 \% \\
)\end{array}$ & $\begin{array}{c}3 \\
(14 \% \\
)\end{array}$ & $\begin{array}{c}0 \\
(0 \%)\end{array}$ \\
\hline 9. & & $\begin{array}{l}\text { I set speaking goal such as } \\
\text { being able to speak fluently like } \\
\text { native speakers. }\end{array}$ & $\begin{array}{l}0 \\
(0 \\
\%)\end{array}$ & $\begin{array}{c}0 \\
(0 \%)\end{array}$ & $\begin{array}{c}1 \\
(5 \%)\end{array}$ & $\begin{array}{c}21 \\
(95 \% \\
)\end{array}$ \\
\hline $\begin{array}{l}1 \\
0 .\end{array}$ & & $\begin{array}{l}\text { I evaluate the progress of my } \\
\text { speaking ability and correct the } \\
\text { mistakes I do in speaking } \\
\text { English. }\end{array}$ & $\begin{array}{l}0 \\
(0 \\
\%)\end{array}$ & $\begin{array}{c}2 \\
(9 \%)\end{array}$ & $\begin{array}{c}19 \\
(86 \% \\
)\end{array}$ & $\begin{array}{c}1 \\
(5 \%)\end{array}$ \\
\hline $\begin{array}{l}1 \\
1 .\end{array}$ & \multirow{2}{*}{$\begin{array}{l}\text { Affecti } \\
\text { veStrat } \\
\text { egies }\end{array}$} & $\begin{array}{l}\text { I take deep breath before } \\
\text { starting speaking English in } \\
\text { front of many people to reduce } \\
\text { anxiety. }\end{array}$ & $\begin{array}{l}0 \\
(0 \\
\%)\end{array}$ & $\begin{array}{c}6 \\
(27 \% \\
)\end{array}$ & $\begin{array}{c}10 \\
(46 \% \\
)\end{array}$ & $\begin{array}{c}6 \\
(27 \% \\
)\end{array}$ \\
\hline $\begin{array}{l}1 \\
2 .\end{array}$ & & $\begin{array}{l}\text { I say positive statement to } \\
\text { myself which encourages me to } \\
\text { speak English inside and } \\
\text { outside the classroom. }\end{array}$ & $\begin{array}{l}0 \\
(0 \\
\%)\end{array}$ & $\begin{array}{c}4 \\
(18 \% \\
)\end{array}$ & $\begin{array}{c}15 \\
(68 \% \\
)\end{array}$ & $\begin{array}{c}3 \\
(14 \% \\
)\end{array}$ \\
\hline $\begin{array}{l}1 \\
3 .\end{array}$ & \multirow{2}{*}{$\begin{array}{l}\text { Social } \\
\text { Strategi } \\
\quad \text { es }\end{array}$} & $\begin{array}{l}\text { I practice my speaking with my } \\
\text { friends such as having } \\
\text { temporary pair or small group. }\end{array}$ & $\begin{array}{l}1 \\
(5 \\
\%)\end{array}$ & $\begin{array}{c}5 \\
(23 \% \\
)\end{array}$ & $\begin{array}{c}10 \\
(45 \% \\
)\end{array}$ & $\begin{array}{c}6 \\
(27 \% \\
)\end{array}$ \\
\hline $\begin{array}{l}1 \\
4 .\end{array}$ & & $\begin{array}{l}\text { I practice my speaking by } \\
\text { having conversation with native } \\
\text { speakers that I meet outside the } \\
\text { classroom. }\end{array}$ & $\begin{array}{l}1 \\
(5 \\
\%)\end{array}$ & $\begin{array}{c}12 \\
(54 \% \\
)\end{array}$ & $\begin{array}{c}9 \\
(41 \% \\
)\end{array}$ & $\begin{array}{c}0 \\
(0 \%)\end{array}$ \\
\hline
\end{tabular}

SD: (Strongly Disagree); D: (Disagree); A: (Agree); SA: (Strongly Agree)

The findings from the questionnaire were also supported by the interview results of some students. A student said that she joined English club 
because there were many native speakers who joined the club. Therefore, Indonesian people including her were demanded and forced to speak and communicate in English with both native speakers and other Indonesian people. Another student explained that she made a routine schedule in which twice in a week she had to practice her pronunciation over and over and also her grammar by doing grammar tasks. When there was free time, she also used it to practice her speaking.

\section{The Use of the Strategies in Relation to the Students' Self- efficacy}

Based on the questionnaire result, 21 students or $95 \%$ agreed that their speaking ability was improved after doing some language learning strategies while one student or $5 \%$ disagreed. It means that the strategies were useful for speaking improvement of most students. The improvement was reflected in their speaking performance after applying various language learning strategies. The researcher did not determine whether their performance was really improved by seeing their performance directly, but by trying to make meaning on their perception of their speaking ability.

The questionnaire result was supported by the interview result of three students. Student B and student $\mathrm{C}$ explained that their speaking ability is really better because now they can respond to the conversation faster without thinking too long about what I have to say and understand more how to speak English politely and formally by choosing appropriate vocabularies and correct grammar. However, student A who disagreed explained that her speaking ability did not get better even though she did language learning strategies like what her friends did. It happened because she did not do them seriously which meant that she could not persist in facing obstacles even though actually she really wanted to have better speaking ability and be able to speak English as fluent as native speakers. Moreover, she was not confident in her speaking ability and she had doubt that she would be able to achieve her goals. From the analysis, it can be concluded that the improvement were obtained by only student $\mathrm{B}$ and student $\mathrm{C}$.

The improvement was not obtained by all students because of some factors that influenced the use of language learning strategies, namely motivation and anxiety (Oxford, 1990). Student B and student $\mathrm{C}$ were those whose motivation were high and anxiety was low, while student A was a student whose motivation was low and anxiety was high. Because of the high motivation and low anxiety had by student $\mathrm{B}$ and student $\mathrm{C}$, they were more successful than student A as reflected in their speaking performance after applying language learning strategies.

The analysis of the use of strategies and factors influencing it were used to determine students' self-efficacy. The researcher used the 
analysis of targets and goals set by the students to analyze task orientation and the analysis of language learning strategies were applied by the students to analyze strategy use. Moreover, the researcher used the analysis of factors that influence the use of language learning strategies, namely motivation to analyze effort \& persistence and personality trait to analyze beliefs.

Table 4 below shows aspects influenced by self-efficacy which determined students' self-efficacy. From the table, it can be concluded that student A had low self-efficacy while student B and student $\mathrm{C}$ had high self-efficacy.

Table 4 The Influence of Self-efficacy on Students' Learning Strategies

\begin{tabular}{|c|c|c|c|c|c|}
\hline $\begin{array}{c}\text { Interviewe } \\
\text { e }\end{array}$ & $\begin{array}{c}\text { Task } \\
\text { Orientatio } \\
\text { n }\end{array}$ & $\begin{array}{c}\text { Effort \& } \\
\text { Persistenc } \\
\text { e }\end{array}$ & $\begin{array}{c}\text { Strateg } \\
\text { y Use }\end{array}$ & $\begin{array}{c}\text { Belief } \\
\text { s }\end{array}$ & $\begin{array}{c}\text { Performanc } \\
\text { e }\end{array}$ \\
\hline A & $\checkmark$ & $x$ & $\checkmark$ & $x$ & $x$ \\
\hline B & $\checkmark$ & $\checkmark$ & $\checkmark$ & $\checkmark$ & $\checkmark$ \\
\hline C & $\checkmark$ & $\checkmark$ & $\checkmark$ & $\checkmark$ & $\checkmark$ \\
\hline
\end{tabular}

Bandura (1986) states that high selfefficacy individuals will have higher performance than low self-efficacy individuals with the same ability and under particular condition. It means that low self-efficacy individuals will have lower performance than high self-efficacy individuals. Based on the questionnaire and interview results, student $\mathrm{B}$ and student $\mathrm{C}$ performed their speaking better than student A even though all of them did some language learning strategies. It shows that student $\mathrm{B}$ and student $\mathrm{C}$ had high self-efficacy while student A had low selfefficacy. Therefore, it can be concluded that the higher speaking performance they had, the higher students' self-efficacy.
Bandura (1986) states the higher targets and goals they set and the more useful strategies individuals do, the higher their self-efficacy. Not only having high targets or goals, they also do some things to achieve their targets and goals. All students who became the interviewees demonstrated as high self-efficacy individuals as seen from two aspects, namely task orientation and strategy use. The first reason was because they set high goals which were having better speaking ability, being able to speak English as fluent as native speakers and the other goals even though they had different beliefs in their speaking ability. The second reason was because not only setting high goals, all of them did some language learning strategies which were divided into direct 
strategies and indirect strategies to achieve their goals

The more effort they put when facing obstacles, the higher students' self-efficacy (Bandura, 1986). Student B and student C were individuals who had high selfefficacy because they never gave up when facing obstacles. They even put more effort to remove the obstacles to achieve their goals such as forcing themselves to keep speaking English even though their speaking ability was not perfect, gaining more confidence and strengthening their belief in their speaking ability. On the other hand, student A was someone who could not continue doing the strategies when the obstacles appeared. She easily gave up because she doubted her speaking ability. It means that student A's self-efficacy was low.

The more confident and more able to control their stress and anxiety, the higher students' selfefficacy (Bandura, 1986). Student B and student $\mathrm{C}$ were those who had high self-confidence that they would be able to have better speaking ability, speak as fluent as native speakers, and achieve other goals they set. Moreover, they could control her anxiety, fear and stress in certain condition which made her choose to be a responsible person who kept trying and believing in her ability. Nevertheless, student A was the one who was not sure that she could achieve her goals because she was not confident in her ability. She was afraid that she could not achieve her goals because of her ability.
From the analysis of beliefs, it is concluded that student $\mathrm{B}$ and student $C$ had high self-efficacy while student A had low self-efficacy.

\section{Conclusions}

First, the research findings indicated that all students applied various language learning strategies in order to improve their speaking ability. Those strategies were divided into six groups, namely memory strategies, cognitive strategies, compensation strategies, metacognitive strategies, affective strategies and social strategies. The most dominant strategy was setting speaking goal because $100 \%$ of the students applied that strategy. According to Oxford (1990), this strategy belongs to metacognitive strategies.

Second, language learning strategies were useful for almost all students, as reflected in their speaking performance which was improved. The use of those strategies was influenced by some factors, namely motivation and anxiety. The higher motivation and the lower anxiety the students had, the more strategies were used and the more successful they were in learning foreign language. The success was reflected in their speaking performance after applying various strategies.

Other aspects were influenced by self-efficacy also determined students' self-efficacy. In short, the higher targets and goals set by students, the higher students' selfefficacy; the more effort students 
put, the higher students' self- efficacy; the higher students' efficacy; the more useful strategies speaking performance, the higher they applied to achieve their goals, the higher students' self-efficacy. Moreover, the more confident and more able to control their stress and anxiety, the higher students' selfstudents' self-efficacy. Based on the analysis of those aspects, it was found that student A had low selfefficacy while student B and student $\mathrm{C}$ had high self-efficacy.

\section{References}

Bandura, A. (1986). Social foundation of thought and action: A social cognitive theory. Englewood Cliffts: Prentice-Hall.

Bandura, A. (1997). Self-efficacy. The exercise of control. New York: W. H. Freeman and Company.

Gardner, R. C. (1985). Social psychological aspects of language learning: The role of attitudes and motivation. London: Edward Arnold.

Harmer, J. (1991). The practice of English language teaching. Harlow, Essex: Longman.

Horwitz, E. K. (2001). Language anxiety and achievement. Annual review of applied linguistics, 112-126.

McDonough, J., \& Shaw, C. (2003). Materials and methods in ELT: A teacher's guide $\left(2^{\text {nd }}\right.$ ed.). Oxford: Blackwell Publishing.

Oxford, R. L. (1990). Language learning strategies: What every teacher should know. Boston: Heinle \& Heinle Publishers. 